\title{
The development of modern Jingdezhen ceramic school vocational education enlightenment
}

\author{
Xiu-mei wu \\ University of Jingdezhen, ceramic institute of design art, 333403
}

Keywords: Jingdezhen, ceramic education, Development of enlightenment

\begin{abstract}
Qing guangxu twenty-nine years (in 1903), the governor of Jiangxi province ke time to the qing government suggested "revitalization of the craft, and poly rights", and making the hubei alternate way Sun Tinglin "so China company, raise two dial the silver to interface, more shall be set by the way, have reportedly five describe, in the town set up in March, which he called workers specially made YangShi porcelain will be fine will be fine, or so the autumn can shipment". Xuantong two years (in 1910), Jiangxi Jingdezhen porcelain company was formally established, hired from the Japanese ceramics school graduation returning dialectical adopts the mechanical system porcelain, mines fire test. Established in January 1929, Jiang Xitao service, tao 1930 service merge in provincial industrial experiment, in 1932, restructuring of contented industry experiments
\end{abstract}

Republic of capitalist economic development, greatly changed the original mode of production process. Mechanical professor passed down through the introduction of the original mentoring process methods on the quality and quantity cannot adapt to the social demand for talents. And group of the first line has entered the production workers also need training again, so as to adapt to the change of the mode of production process. Changes have made a series of reform of Jingdezhen porcelain industry faces a serious shortage of porcelain making the plight of skilled workers, as a result, the qing xuantong two years (in 1910), school of the ability of Chinese contented industry in the province Yang county halls, affiliated to Jiangxi porcelain industry company rao, the funds raised to the enthusiastic educators, Jiangxi porcelain industry company in the society each tire east and funded, recruit undergraduate class contented industry, high graduates aged 15, length of schooling for three years. But new porcelain industry school has experienced a series of change such as open, close, and changed its name, the revolution broke out in 1911, unable to raise capital, Jiangxi porcelain industry company rao state factory was forced to shut down, contented industry school is closed because of funding problems. First year of the republic of China (1912) by Jiangxi nazim (governor) Li Liejun will school ability of Chinese contented industry, under the province do, changed its name to "Jiangxi rao state contented industry school", the first President zhang hao, the nature of higher vocational schools have contented industry undergraduate and prep, will give state porcelain industry to the school-run factory. Four years of the republic of China 
(1915), the school changed its name to "' Jiangxi first dimethyl industrial school, apply to the national, directly under the ministry of education, entitled" national contented industry school ", after the postponement for straight anhui war. Handle in Jingdezhen in 1916, called the "school of Jiangxi industry". On site is located in Jingdezhen west YuanMen (bi home initiates the back door of the factory), for primary vocational school, soup is light served as the school learning, nine years of the republic of China (1920), suspension, in 1924, Jiangxi x industrial reorganization of "Jiangxi ceramics school" school. Jingdezhen, namely the "school of Jiangxi industry". In 1926, Jiangxi Jingdezhen ceramics school by province Yang moved, changed its name to "Jiangxi Jingdezhen contented industry school". In 1934 the school moved to jiujiang, was changed to "Jiangxi jiujiang ceramics division vocational school". In 1937 the school moved from jiujiang to JingAn county, in 1938 and moved to pingxiang county port town, 1944 moved to Jingdezhen, and the float saddle county ceramic vocational schools merge. Upgraded to Jiangxi contented industry college in 1945. Actually school upgraded to a junior college also took a lot of trouble, tao school to recruit ZhuanKeBan thanks to two things: first, in 1946, Wang Fan was Chiang kai-shek summoned in lushan mountain, so make hay while the sun shines to Chiang kai-shek, the careful design and production of a batch of national gift porcelain, ceramic education to upgrade and taken advantage of the proposed specialist. Second, the school to accept a batch of Britain's queen Elizabeth wedding gifts porcelain production tasks, teachers of "dragon playing pearl" won the queen's favorite gift porcelain. The success of these two period makes the education minister zhu jh facta at school on the group of eight words: "must do the specialized subject, still attached to the tao". On May 30, 1948, the republic of China in Jiangxi daily load is must set up a contented industry college, the original text is as follows:

Provincial tao ZhiGai for junior college, not approve by the ChengFeng twice the ministry of education. Nearly double, according to the request of the member, and in view of the fact there are necessary, decided to establish provincial contented industry college alone. Original ceramic of vocational schools affiliated to deal with, and approved by Chen Li, to the force, please engrave has officially serve must deal with. Founded in Jingdezhen, Jiangxi contented industry junior college Wang Fan presidents, it is not only in institutions of higher learning in the provincial capital of nanchang in Jiangxi province. Development to 1949 has specialized subject of five classes, secondary six classes, 238 students, faculty and 55 people. Main teachers Wang Fan, Wang Chen, Dai Cui new, many, xin-wei shu, Wan Hao, dantes Xie Guchu and check ZongLu, Pan Yong grasp, Zhang Zhishang, etc.

With the continuous development of porcelain industry, Jingdezhen porcelain industry school also constantly build, 20 years of the republic of China (1931), the float saddle county decorative porcelain vocational schools set up. Site in Jingdezhen lotus pond. First President Feng Yuan, graduate recruitment is high, length of schooling for three years. 25 years of the republic of China (1936) into the school and Jingdezhen middle school "the float saddle county ceramics division junior vocational schools", graduated from nanjing liangjiang normal school of fine arts of the soup has worked 
in the school as the principal of light, the famous porcelain painter Fang Yunfeng, Wang Ye pavilion, BiBoTao, Zhang Zhishang, cheng Italian pavilion has taught in the school. In 1944, Jiangxi jiujiang vocational school moved to Jingdezhen, ceramics and "the float saddle county ceramics division junior vocational schools" to merge, the next year instead of "Jiangxi ceramics division vocational school". In May 1948, approved by the ministry of education "Jiangxi ceramics division vocational school" instead of "Jiangxi ceramic school". Contented industry school successive presidents, respectively is: the first dialectical, the second chapter in the south, third Zou Junzhang, fourth zou as kei, dialectical and 1932 fifth principal, 6 Ren Shu, seventh Wang Fan. Of countrywide college courtyard was adjusted 1953, Jiang Xitao industry school (college) suspension of engineering students go to the south China institute of technology, art students turn to Jiangxi art college, professional class students go to the hunan xiangtan electrical appliance manufacturing school.

Porcelain industry school for the establishment of the porcelain industry company has trained a large number of porcelain painting porcelain talent, they are involved in the development of the industry innovation, the school when the teacher, the others involved in the industry for the development of Jingdezhen porcelain industry and school provides a lot of help, such as "pearl mountain eight friends" in the Italian pavilion, cheng graduated from Jiangxi x industrial school. Meike cen, who graduated from the school of Jiangxi industry, taught at the float saddle county ceramic vocational school; Wang Ye pavilion, graduated from contented industry school. And eight friends "' pearl hill with paintings of wang too pathetic, Fang Yunfeng, Zhang Zhishang also is such. Wang too pathetic graduated from the school of Jiangxi industry, in Jiangxi province after contented industry junior school: Zhang Zhishang in 1935 at the float saddle county decorative porcelain junior vocational school, in 1945 in Jiangxi contented industry at school. With the establish of Jingdezhen porcelain industry school, the other porcelain producing area also have established porcelain industry school, such as qing guangxu thirty-one years, hunan institute declared dispatch Xiong Xiling tens of thousands of words in the book are HuGuang while governor, urged in liling porcelain industry school and the porcelain industry company. The following eighteen thousand two hundred, the qing government to approve the dial yaguan parilion establish hunan porcelain industry school, ceramic painting, windlass, educational model, recruit students more than three hundred people.

Anyhow, ceramic vocational school founded were made by the ancient ceramic history some initiative, not only for early modern industry has made outstanding contributions to the development, but also for the real revival of China industry has trained a large number of professional talents. Which has a certain scale and influence, remarkable achievements have school (1910), the ability of Chinese contented industry in Jiangxi province (1913), Jingdezhen contented industry junior school b industrial school (1916), the float saddle county decorative porcelain junior vocational school (1931) Jiang Xitao industry professionals to develop private Oriental art (1935), schools (on the eve of the founding), etc. Organize contented industry in our country school motivation is the improved industry development present situation, the 
conservative, hidebound porcelain making traditional way can't fight against foreign goods, ceramics must be improved, and the improved besides run industries, the key is to cultivate new talent. The first in the history of Chinese ceramics vocational schools - school ability of Chinese contented industry. Its tenet is: "develop understand theory, talent and advanced technology, with improved contented industry".

- Porcelain industry school teaching object

Democratization and popularization of the new culture movement advocated education, under the guidance of the ideological trend, education to rationalize taken the first step - the range of adjusting teaching, expanding, a professor at the object, to meet the needs of the society. The popularity of education is the education to - a symbol of democracy. Influenced by the whole Chinese education teaching object change, pottery and porcelain in Jingdezhen porcelain industry school reform education has made great adjustments. Du Chongyuan first to recognize that, to reform the industry must be improved CiRen first, to improve CiRen, education must first modification industry. Jingde town is located in a remote mountainous area, at that time people thought more conservative, the new knowledge at that time the difficult to accept, if you don't have a batch of scientific knowledge, understand the world situation of contented industry technical personnel to take the lead, the reform of Jingdezhen porcelain industry is hard to imagine. Yu Shidu's adopted a series of reforms:

First, using ceramic education universal age positioning between 12 to 18, the ranks of the secondary education category, six years of schooling. For the students of this age, to quickly change their minds is relatively easy 。

Second, in addition to change age on its teaching object. The change of the porcelain industry education teaching object is performed in the women's education. Jingdezhen because of traffic block, culture education not developed for a long time, women's education is a piece of blank paper. Against the old feudal ethical code poison women for a long time the women came out from the bottom society promoted, Yu Xinguo in Jingdezhen in the autumn of 1914 created the first "'" women's college. Women's college in the original primary students, four years of schooling, 1920 high students. School courses have society, Chinese, arithmetic, natural, gymnastics, music, manual, history, geography, etc. Feng jiu ge in the autumn of 1925 founded the Jingdezhen female "' pearl mountain, students up to more than one hundred people, equipped with beginner and advanced, four classes. As Jingdezhen's first women's college and the establishment of the bead mountain women education, learning skill woman entered the classroom this phenomenon in Jingdezhen is more and more prominent, especially women of ceramic painting more 。

Third, is the attention of the students in rural areas. Traditional Jingdezhen porcelain making technology and has close ties to the countryside is the vast number of means of peasant household, so the rural vocational education in the general course more attention to the process. For rural students before training is also a modern phenomenon, not by modern before due to the influence of the feudal forces, only the rich children to enter school to study, there is no chance to step into the school of the 
poor. This at the time of the porcelain industry is a key initiative in education. Rural students can bear hardships and stand hard work, they learn skills when the focus is more serious, this will speed up the development of the industry 。

Fourth, expand the scope of admissions. School recruit students is not only limited to Jingdezhen surrounding areas, but the national admissions, especially encouraged students in big cities, because students from big cities, they thought relatively open, relatively high cultural quality. Such as Du Chongyuan in the spring of 1935, in Shanghai, nanchang, enrolled more students graduating from high school, eighty. Expanding the scope of the admissions for Jingdezhen porcelain industry has played a great role in promoting。

Below as part of Jingdezhen ceramic vocational school as an example, analyzing the change of the modern ceramic education during the period of teaching object: Jiangxi contented industry college: qing xuantong two years, founded by zhang hao in the province Yang county. After the xinhai revolution type Jiangxi industrial ceramics school instead. In 1945, the school upgraded to Jiangxi contented industry college, ceramic engineering and ceramic arts, to recruit high school graduates, ceramic engineering courses in higher mathematics, physics, engineering mechanics, ceramics, chemical, mechanical, kiln, ceramic raw materials science, history of Chinese ceramics, glass, enamel and cement, etc. Ceramic art courses have sketch, western painting, Chinese painting, pottery and porcelain enamel, ocean color, ancient color, blue and white pattern, etc 。

Contented industry: school in Jiangxi province in 1916 the first dimethyl industrial school, set up campus. School recruitment of students scope, involving anhui, zhejiang, Jiangxi, Jingdezhen. Make porcelain after school do first ceramic professional class, professional class, beginning recruit undergraduate class contented industry, into two groups, porcelain, act the role of porcelain meter six classes, graduate more than 15 years old is high, length of schooling for three years. Attached do apprentice class, junior middle school culture more than 12 years old boy, consists of five years. Implements the "three-thirds system", there are seven classes, students in 42 people including 3 female students), students of most hundreds. Contented industry schools not only has its important position in the history of startan undertaking education, but also for the development of Chinese ceramic art and porcelain making technology, also has made a significant contribution。

From above school, recruiting object has the following characteristics, namely the recruit students of wide area, old age, boys and girls unlimited, etc. This fully embodies the modern period Jingdezhen's emphasis on education of pottery and porcelain, porcelain industry education teaching object adjustment greatly promote the development of Jingdezhen porcelain。

二、 the porcelain industry school curriculum is rich

New ceramic education school to learn from other school curriculum pattern, such as national art school in Beijing in the late qing dynasty division (middle, high) (1918) can be divided into professional internship, theory, science and technology, several large classes 。

By reference to other college courses according to their own characteristics of ceramic 
technology education to set up, as a result, a slightly different schools curriculum, develop the course setting is relatively complete, have spirit to give lectures, political science, economics, sociology, law, company law, accounting, statistics, summary, ceramic theory, build kiln, pictures, send color, ceramics production survey, practical writing, etc., also started the English, Russian, Japanese electives, Sun Xiulin (teacher), company law and politics Li Bao (teacher), legal sun jing (teacher). Contented industry college in 1947 set of ceramic engineering, ceramic, fine arts, to recruit high school students。

Contented industry school is set up, i.e. points act the role of porcelain, two classes a China. Decorative porcelain class every Monday, three, five basic knowledge learned in the classroom and paper for painting, painting porcelain, into the factory two, four, six general entrance half a year can be painted porcelain, create value directly. Class to learn a China forming and clinkering, the number of class a China rarely. Around like act the role of porcelain of students graduate, I fight, so trained students can directly used for the society. Such as in situ painter wang too pathetic, Du Ta of ceramic art is acted the role of porcelain class. Secondly, ceramic engineering, department of potters have assisted subjects such as advanced mathematics, physics, chemistry, engineering mechanics, the specialized ceramics, ceramic mechanical, kiln, ceramic raw materials, history of Chinese ceramics, glass, enamel and cement, etc. Basic course of art to have a sketch, western painting, Chinese painting, specialized courses is ceramic famille rose, the color, the ancient color and decal design, etc. The curriculum structure, therefore, still prefer to practice, and theory research, this kind of situation in the $30 \mathrm{~s}$ to change 。

From the courses, the new education curriculum appears more rich, more in line with the needs of the development of ceramic education and ceramic industry. It clearly is not just to develop general ceramics technology professionals, and to cultivate a batch of ceramic handicraft exports, communicate with foreign business talents, to the revitalization of China's ceramic technology, promote the ceramic production and marketing, improve the international reputation. Because the pattern is not general porcelain making talent cultivation, but has a comprehensive knowledge and skills and a liberal art theory. The increase of other classes, such as historiography, and natural history course open, more enrich the students' learning and historical knowledge, so they can on the ancient and modern, Chinese and foreign culture have a general understanding of knowledge, in the era of the expansion of the foreign goods can correctly treat the Chinese traditional craft. From the subjects of study of increasing, expanding the scope of the teaching to the curriculum setting and adjust the course structure step by step of the process, we can see that ceramic education is developing gradually in the direction of the rationalization. We can see education absorption of Jingdezhen porcelain design education mode is improved using both at home and abroad, make it more beneficial to the ceramic technology development 。

三、 the structure of the porcelain industry school knowledge update

From the late qing dynasty to the early, ceramic education system in China, such as educational system, curriculum is basically a transplant from Japan, its design education system of China's ceramic education laid a solid foundation. In addition, the 
education system for reference to other European countries in the education of learning and try to also increase gradually. In the modern period of Jingdezhen ceramic education especially attaches great importance to the design of decoration design. Ceramic decoration at this time is no longer subject to the sample of court, but to be innovative. Must have the innovation requires that students must master the comprehensive knowledge system, not only will mechanically copying predecessors' work. So the ceramic on the courses in the school had the very big change, cultural and professional are included in the scope of teaching, so that training students thinking, thinking and innovation。

Can be seen through the above analysis of Jingdezhen ceramic education is not only influenced by other domestic institutions of higher learning technology course, and introduce the foreign teaching mode, the first is influenced by Japan, such as Wang Fan, as an early Chinese students studying in Japan to compare the method of system study to the modern porcelain making technology, after returning the ceramic knowledge systematically applied to the Jingdezhen porcelain. Second, contented industry school on teaching by using the new way of teaching, to foster specialization technical talents for the principle, pay attention to the combination of number, science,. Professor zhang hao personally specialized courses, and by operating the new machine and kiln technology personnel training. He will spare state porcelain industry instead of school-run factory, the factory promotion step by step in plaster cast slab, mechanical jigger compact brush flower decals, the color, and he personally to build new mines. Du Chongyuan also lectures, teaching mainly follow huang yanpei investigation of Jingdezhen in 1914 after the train of thought, to make our teaching theory combined with practice, in the training of specialists in the field of ceramics at the same time, also trying to promote new technology, factory set up a teaching experiment, porcelain making, grouting, molding machinery, such as the experiment and teaching。

\section{Conclusion}

In a variety of teaching methods to study, Jingdezhen ceramic education appeared diversified situation. A batch of advanced intellectuals advocated by science and education, not only pay attention to the teaching of scientific knowledge, more emphasis on learning the spirit of science, the study of experimental science research methods. The common characteristics of these teaching methods are: attaches great importance to the problem, combining theory with practice and to overcome the traditional teaching method in the stay read speakers, from theory to practice, the disadvantages of educatees individuality development. 1917 bear Zhu high in "practical manual reference" is put forward on the construction method of professor, "of your tutoring," rather than "mandatory and binding" so, shall have the scope of the "play". This kind of teaching method to improve students creative and practical ability. In addition, the teaching method is scientific also received attention。

References:

1, xiu-mei wu: The evolution of the Jingdezhen ceramic education from modern times to the modern, nanchan, Jiangxi fine arts publishing house, 2016.11。

2, xiu-mei wu: the inheritance and change - Jingdezhen porcelain development 
research of the republic of China, Beijing, guangming daily press, 2012, 5 。

3, xiu-mei wu: the traditional handicraft culture research - ceramic hangzhou fan, for example, Beijing: guangming daily press, 2013, 5 。

4, zhen-fan wan, Lin Songhua editor: studies of modern times social transformation in Jiangxi, Beijing: China social sciences press, 2001。

5.XiChuan performance: "the classical works of design art anthology, nanjing: southeast university press, 2002。

Xiu-mei wu, female, doctor of design art, in fuzhou, master instructor, research direction: the art of design principle, industrial design and theory, ceramic art design and theory.

This paper is the Jingdezhen ceramics university center for collaborative project: "Jingdezhen ceramic art education from the evolution of modern times to contemporary"。 